\title{
The fallacy of designing for in-perpetuity: geotechnical presumptions, ecosystem responses and concepts for managing inevitable change
}

A.B. Fourie The University of Western Australia, Australia

M. Tibbett Department of Environmental Science and Technology, Cranfield University, UK

J. De Jong University of California, USA

\begin{abstract}
The design requirement for the performance of covers to tailings storage facilities and waste rock dumps is increasingly being stipulated as being 'in-perpetuity'. This is often interpreted as being in excess of 1,000 years. There are no other geotechnical systems that have a design life anywhere as long as this. Geotechnical systems such as earth dams, slopes and foundations, which typically have design lives of 50-70 years, are designed on the basis of engineering properties measured during and immediately after the design and construction process. Implicit in this approach is the assumption that these properties do not change with time. However, in the case of cover systems, a number of ecological factors are likely to cause changes in properties such as hydraulic conductivity, density and strength, with time. We give examples of how the initial geotechnical design assumptions are not stable and will inevitably change as the system evolves.
\end{abstract}

Typically, starting from an inert biologically barren system, through the process of carbon fixation (photosynthesis) and energy capture, the biological, chemical and physical properties of these structures will change. These changes may sometimes be considerable (order of magnitude) and sometimes occur with surprising speed (a few years, not centuries). We go on to consider ways in which harnessing nature and inevitable (eco-)system change might be brought into the planning and design of post-mining landforms. We propose that the days of geotechnical design as the sole concept in mining should evolve into biogeotechnical design, where inevitable change is harnessed to enhance the properties of the new land system, rather than degrade it.

\section{Introduction}

In a Keynote lecture at the 2007 Mine Closure conference, Fourie and Tibbett (2007) presented a graphic summarising the key message of their lecture, reproduced as Figure 1.

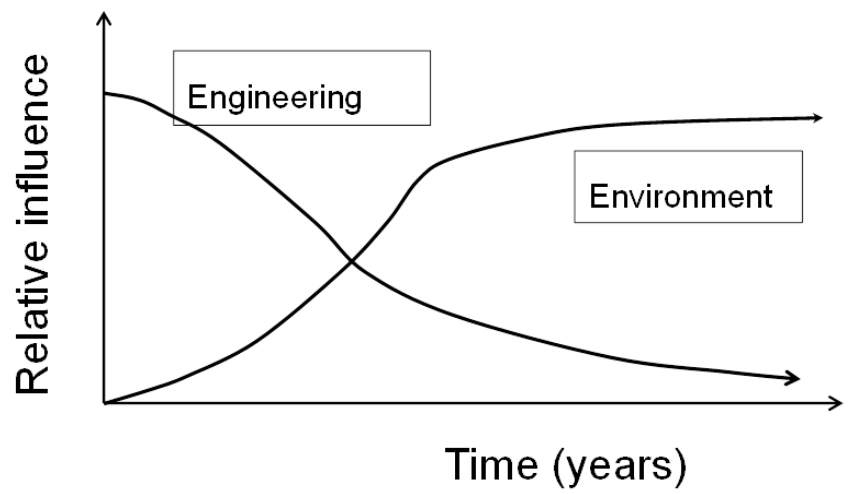

Figure 1 Relative influence of engineered construction versus evolving environmental impacts during the life of a closed facility 
For a hypothetical closed facility (such as a tailings storage facility (TSF)), they argued that at the completion of the engineering work required to close the facility, the influence of the engineering contribution to the performance of the facility is at its peak. Examples include any drainage facilities such as spillways, chutes or stilling basins that might have been constructed, earthworks required to establish the final desired landform, and measures taken to minimise infiltration into the stored tailings. As time passes and environmental factors (such as erosion, weathering, pedogenesis, vegetation establishment, etc.) increase in importance, the contribution of engineered components decreases, although of course the success of the evolving system will be dependent on the quality of the engineered components. For example, poorly designed storm water management facilities will hasten the detrimental impacts of excessive rainfall. As the relative importance of the engineered components decreases with time, the effects and implications of environmental (or perhaps more correctly ecological) aspects become more important. A fundamental tenet of this paper is that the best chance of success of achieving sustainable closure is for all disciplines to consider the approach suggested here and utilise the understandings provided by all disciplines to design and implement a closure strategy that does not consider any particular aspect or discipline more important than another.

Using a number of examples, the paper illustrates the above problem, highlighting the folly of ignoring processes of landscape evolution that will inevitably occur on a constructed landform. An attempt is also made to provide a suggested way forward; after all, it is pointless regarding all attempts to engineer a better solution as inherently futile unless a viable alternative is provided. We do not subscribe to the former view, but rather suggest that recognition of the interactions that inevitably occur is a first step in managing the transitions in behaviour that are inevitable.

\section{Inevitable processes post-construction}

The period over which properties of a constructed landform change is difficult to predict ahead of time. Additionally, the magnitude of the change and the direction of change (in simple terms, do properties improve or degrade?) may also be difficult to predict. What is almost certain is that they will change. Figure 2 contains a series of charts that schematically indicate changes at length scales from micrometers $(\mu \mathrm{m})$ through to meters $(\mathrm{m})$. The left column represents typical/common terrestrial ecological parameters that would be varied while the right column represents typical/common geotechnical engineering soil properties that would be measured. The trends shown in each figure are based on published studies, some of which are briefly discussed later in the paper, but are presented schematically to emphasise the extent of changes to parameters/properties across all length scales. As evident in Figure 2, the rate of change through time as well as the overall magnitude of change is not consistent or constant. The trends shown indicate broadly predictable increases in each parameter, regardless of scale. The effect on long term geotechnical properties is often less clear. However, some guidance can be provided when the corresponding value for a surrounding natural ecosystem reference site can be given (provided the ecological restoration project is targeting re-establishment of the natural ecosystem, see Tibbett (2010).

Although ecological parameters and engineering properties are shown side by side for various length scales, such as basal tree area directly opposite slope stability, it does not imply that correlations are limited to these 'same scale' dependencies. For example, soil microbial biomass will certainly affect density, but will almost certainly also affect permeability and soil fabric, and perhaps even strength. There are thus a myriad of possible cross-correlations and dependencies between the various parameters and properties shown in the two columns. 

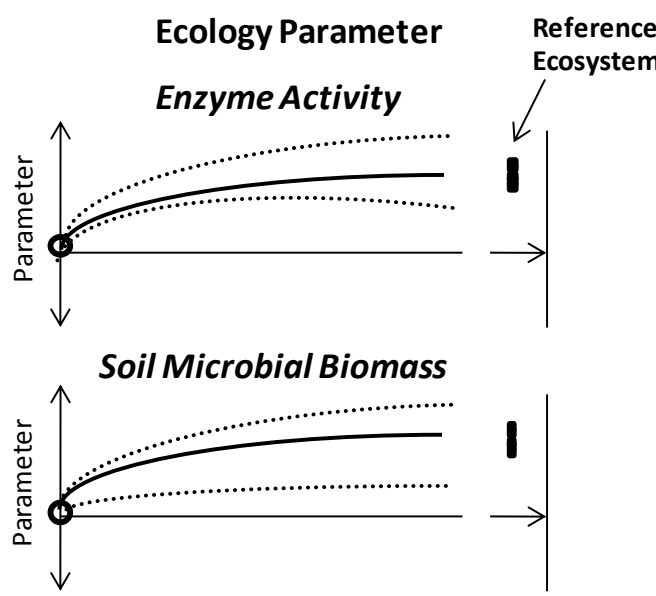

\section{Invertebrate Activity}
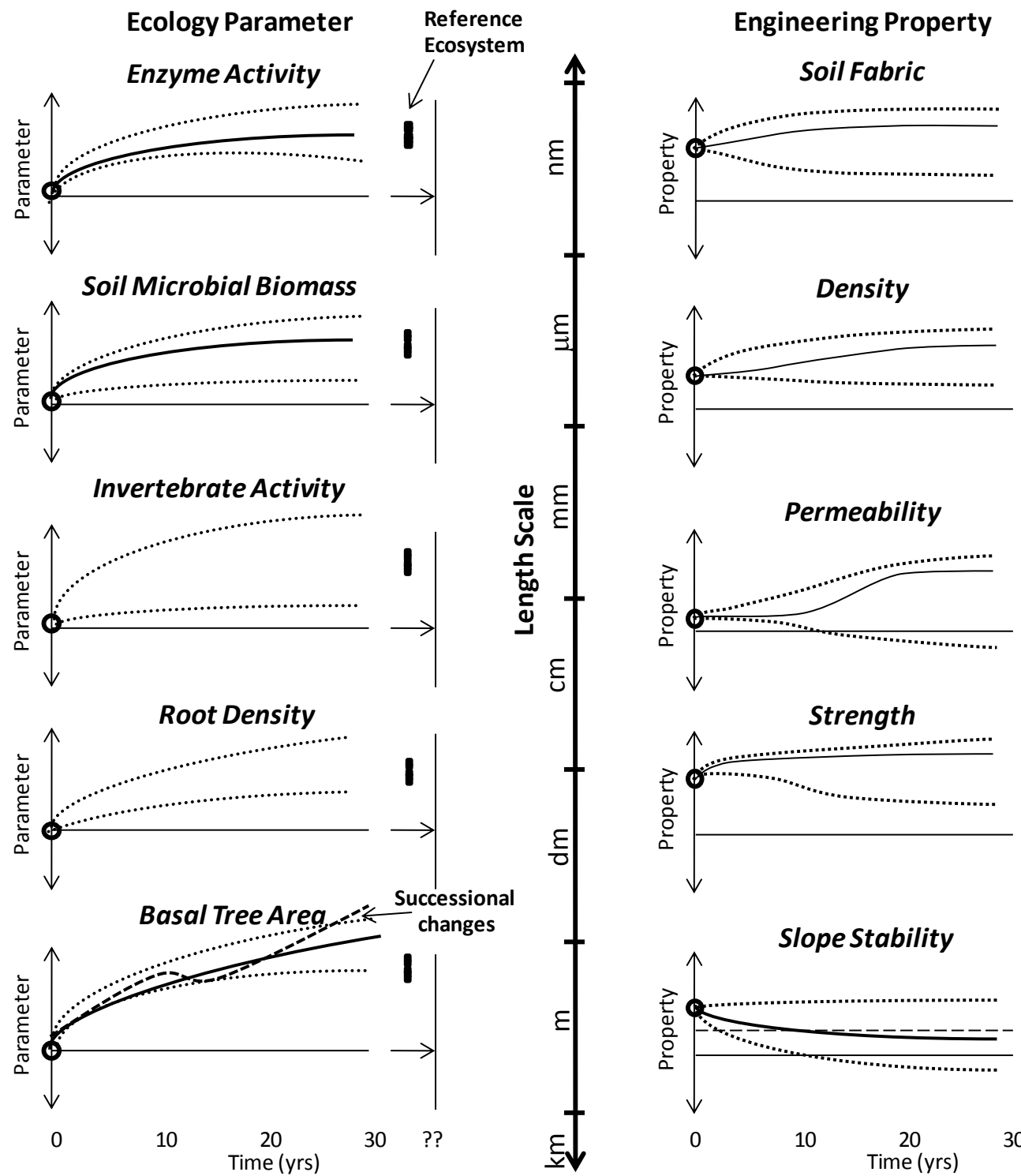

Engineering Property

Soil Fabric

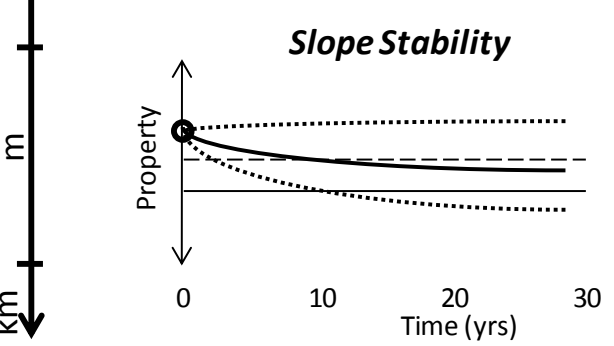

Figure 2 Changes in properties of ecological (left panels) and geotechnical (right panels) parameters across time scales (assuming no biological toxicities)

NB: Temporal trends shown by solid lines are based on observational data from the literature; trends shown by dashed lines are based on either contrasting data sets from literature or where data is limited and dotted lines show anticipated range in trends. The ecological parameters show broadly predictable increases in each measure, regardless of scale, any of which may affect geotechnical properties of soils. Enzyme activities after Spain et al. (2006) for Chitinase [EC 3.2.1.14]; Spain et al. (2009) for $\beta$-glucosidase [EC 3.2.1.21] and acid phosphatase [EC 3.1.3.41]). Soil Microbial Biomass after Spain et al. (2006), Banning et al. (2008). Invertebrates after Majer et al. (1984) and Spain et al. (2010). Root density after Spain and Tibbett (2011) and Spain et al. (2009). Basel tree area after Tongway and Ludwig (2011). Density and permeability after Benson et al. (2007). Strength after Operstein and Frydman (2000), and slope stability after Gray (1970).

According to Mitchell and Santamarina (2005), there are typically about $10^{9}$ to $10^{12}$ organisms in a kilogram of soil near the ground surface. The greater numbers of these organisms are from the microbiota but the great biomass may be from the macrobiota. Bacterial cells in soils are often associated with a substance known as extracellular polymeric substances (EPS), which are usually attached to solid surfaces. This material is generally a complex mixture of macromolecules composed of polysaccharides, protein, lipid, DNA and vitamins (Sutherland, 2001). EPS generally constitutes a very minor component of soils by mass, e.g. Chenu (1995) suggested a value between $0.1 \%$ and $1.5 \%$ of the soil organic matter. Considering the almost miniscule amount of EPS that may be present in a soil, the potential effects are very significant. As an example, Or et al. (2007), presented results of experiments in which small amounts of an EPS analogue (xanthan gum) were added to columns packed with glass beads, after which the hydraulic conductivity of the treated material was evaluated. They compared their results with similar data from the literature, in 
which sand columns were treated with xanthan gum. They found up to five orders of magnitude decrease in hydraulic conductivity with as little as $0.6 \%$ by dry mass addition of xanthan gum. As described by Or et al. (2007), EPS is capable of binding up to $20 \mathrm{~g}$ of water per gram of EPS, thus significantly increasing the water retention capacity of a soil containing even very small ( $<1 \%$ by dry mass) amounts of EPS. Changes of this type and magnitude will probably be very beneficial to store and release type covers.

\section{$3 \quad$ Evidence of evolving engineering parameters with time after closure}

One of the primary considerations when closing and covering tailings storage facilities and waste rock dumps is the hydraulic performance of the cover system. Whether a hydraulic barrier system is adopted (which is being used less and less frequently) or some variant of the 'store and release' cover concept, the hydraulic conductivity of the materials that comprise the cover will be of paramount importance.

There is increasing evidence that the as-constructed hydraulic conductivity will invariably change with time. The US Environmental Protection Agency (EPA) initiated the Alternative Covers Assessment Programme (ACAP) program in 1998 to provide an improved understanding of the hydrological behaviour of both conventional covers (those that include a compacted clay layer or a low permeability geosynthetic) and alternative covers (typically those based on the 'store and release' concept or that include an engineered capillary break layer, or indeed both of these) as final landfill covers. Large-scale lysimeters were constructed at fourteen sites across the US, with a key objective being to study performance in a range of climates, varying from arid to humid and from hot to cold. Trial covers were constructed at all sites, with side-by-side comparisons being carried out at most sites. The field trials were extensively monitored and a key measure was the percolation rate through the covers. The results have been extensively reported in the literature and a succinct review is provided by Albright et al. (2004).

Of particular relevance here are the results obtained from field investigations carried out approximately five years after construction of the field trials (Benson et al., 2007). During construction, samples of the cover soils were recovered by taking block samples to produce truly undisturbed samples. The procedure was repeated in 2002-2004, with most samples being recovered from the near surface (upper $30 \mathrm{~cm}$ ), where most changes in properties were expected. Laboratory tests were carried out on the undisturbed specimens, including saturated hydraulic conductivity tests and soil-water characteristic curve (SWCC) determination using a combination of pressure plate extractors and chilled mirror hygrometers.

The results showed a surprising change from initial, as-placed conditions. With one or two minor exceptions, the hydraulic conductivity increased over time, by as much as 10,000 times in one case. It was clear that the lower the initial, as-placed saturated hydraulic conductivity $\left(k_{\text {sat }}\right)$, the greater was the increase in this parameter over time. The majority of the soils that had initial $\mathrm{k}_{\text {sat }}$ values of $10^{-7} \mathrm{~cm} / \mathrm{sec}$ increased to values between $10^{-5}$ and $10^{-4} \mathrm{~cm} / \mathrm{sec}$. Covers designed as barrier systems were no longer behaving as barriers. Virtually all specimens tested approached $k_{\text {sat }}$ values of between $10^{-5}$ and $10^{-3} \mathrm{~cm} / \mathrm{sec}$ irrespective of the soil texture or the prevailing climatic condition. Within the parameters varied, a longterm $\mathrm{k}_{\mathrm{sat}}$ value less than $10^{-5} \mathrm{~cm} / \mathrm{sec}$ appears overoptimistic and potentially unconservative over the course of the service life, whether this is a prescribed period, or perpetuity.

Similar results were reported for the rate of surface infiltration, measured using static head disc permeameters, at a rehabilitated mine site in northern Australia. As reported by Spain et al. (2006), the effective infiltration rate increased by over five times during the period of study, which was about 26 years. Although this increase was not as dramatic as the hydraulic conductivity changes discussed above, this is probably because of the high initial hydraulic conductivity and low clay content in the surface soils.

Another example is the cover system built for the Rum Jungle waste rock dumps. For the first nine years after construction, the covers performed as designed, with percolation rates being less than $5 \%$ of the annual rainfall. However, after this period the percolation rates increased significantly and were typically between about $8 \%$ and $10 \%$ of the annual rainfall. The results of a comprehensive field investigation are 
contained in the report by Taylor et al. (2003). The investigation was carried out 18 years after cover construction and included in situ hydraulic conductivity tests using a falling head procedure. For all three layers the finding was that the hydraulic conductivity had increased by between one and three orders of magnitude. Trenches were excavated and visual inspection showed extensive occurrence of galleries from termites and ants, development of roots throughout the layers, and the development of polygonal blocks within the compacted clay layer as a consequence of desiccation drying with many roots extending along the cracks between these blocks. Subsequent chemical tests also showed extensive acidification of the cover soils as a result of capillary action drawing moisture upwards from the sulphidic waste material.

It is not only hydraulic conductivity that may change with time. As part of an ecological assessment of revegetated landforms at the Oaky Creek Coal mine, Tongway and Hindley (1998) conducted slaking tests to assess the structural stability of soil samples under immersion in water (modified after Emerson, 1967). The results showed that over a period of about eight years that soils that were initially unstable (i.e. had a high slake propensity) became at least three times more stable. In this case the change was both ecologically and geotechnically favourable.

At a larger geometric scale, the issue of the contribution of roots to soil strength and thus to slope stability has received increasing interest over the past decade or two. There are numerous documented cases of where clearance of vegetation on a slope soon led to slope failures which in general were shallow, translational slides (Bishop and Stevens, 1964; Gray, 1970; Rice and Krammes, 1970; Waldron, 1977; Watson and O'Loughlin, 1985; Gray and Sotir, 1996). These observations have generally led to the conclusion that the tree roots contributed mechanically (i.e. by reinforcement) to stabilisation of slopes (Waldron and Dakessian, 1982), although factors such as rainfall interception, reduced rates of evaporation, and prevention of surficial erosion are clearly also important. Fourie (2007) describes results from a series of triaxial tests on root-reinforced soils, which quantified the mechanical reinforcing effect of roots. In these tests the root content was equivalent to only $0.5 \mathrm{~kg} / \mathrm{m}^{3}$, which is much less than typical values of around 2 to $3 \mathrm{~kg} / \mathrm{m}^{3}$ as quoted by Jackson et al. (1996) for temperate grasslands. Despite the relatively low root density, the minimum increase in shear strength was $6 \mathrm{kPa}$ (from a reference value of $15 \mathrm{kPa}$ with no roots present) and was often greater than this value. Even relatively small increases in shear strength can be very beneficial in preventing the development and propagation of shallow slope failures. As root development occurs in the near-surface region of a soil profile, it can thus provide a reinforcing effect exactly where it is most beneficial, i.e. where it can prevent the development of shallow slides.

\section{$4 \quad$ Incorporating ecological changes into engineering design procedures}

Geotechnical practice traditionally employs a deterministic design methodology wherein the most probable loading conditions and site characteristics are utilised. Site characteristics such as the stratigraphic profile with depth and the soil properties of each respective geologic unit are determined through limited field and laboratory characterisation. The level of uncertainty in characterisation of soil is much larger than that for materials used in most other engineering disciplines (e.g. steel, plastics, concrete) that are manufactured in controlled conditions to specific property specifications (Baecher and Christian, 2003). Similarly, the predicted loading conditions are inherently variable as they are driven by natural processes (e.g. wind, earthquake loading) and variable human behaviour (e.g. traffic levels). To accommodate uncertainty, a safety factor, wherein the predicted load is, for example, doubled during design is traditionally implemented (Terzaghi et al., 1996). In recent years a more advanced probabilistic performance based design methodology has developed to more rigorously account for the uncertainty inherent in both the site characteristics (i.e. soil properties, stratigraphic variability across site) and the loading conditions (Baecher and Christian, 2003). This approach enables the level of uncertainty to be applied in a theoretical manner to specific design inputs, allowing parametric analysis of how the uncertainty in a given variable affects system performance. This approach allows a quantitative assessment to be made of the expected level of performance and the associated probability of failure occurring, as well as the likely cost associated with 
such failure. The results are often presented in a plot such as that shown in Figure 3 (after Baecher and Christian, 2003).

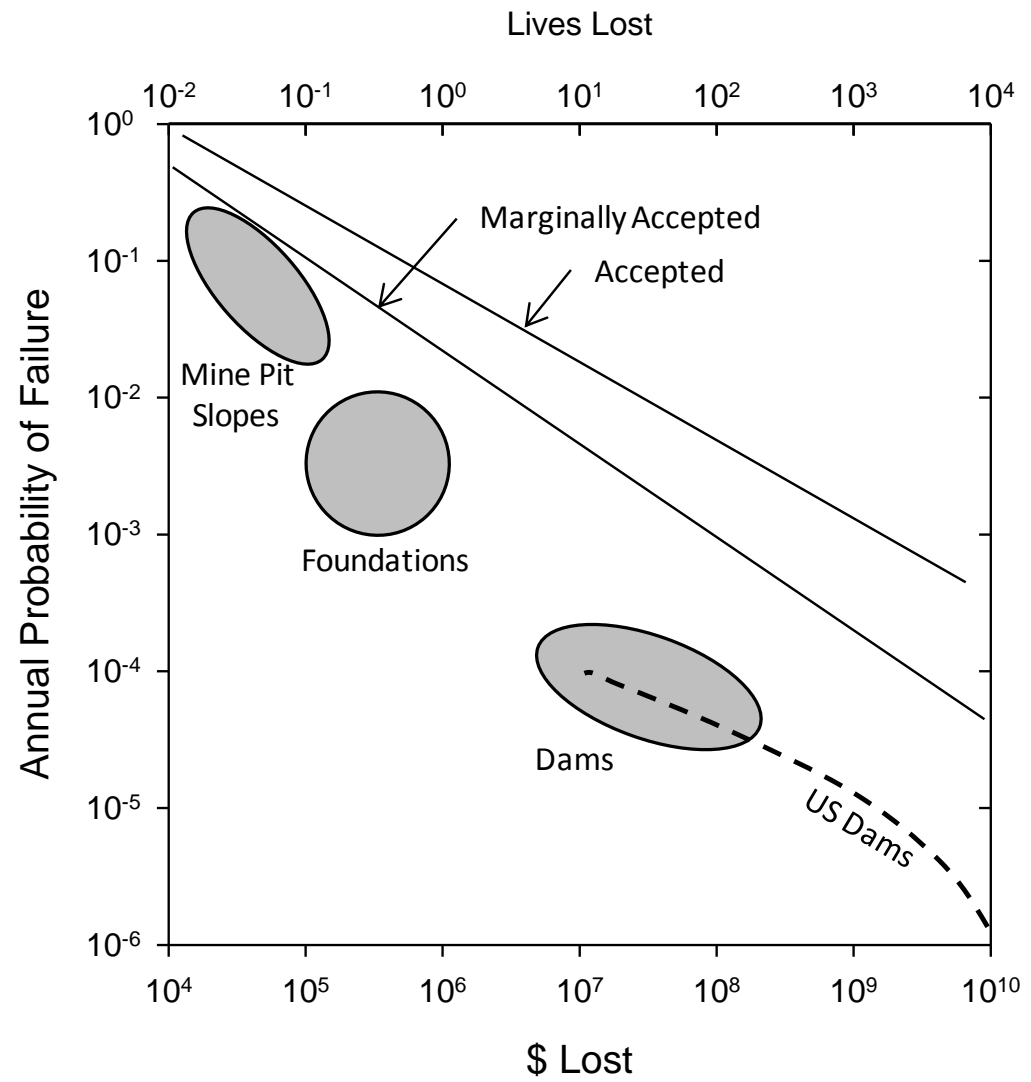

\section{Figure 3 Chart showing risks associated with annual probability of failure for select civil/mining systems (modified from Baecher and Christian, 2003)}

Although the probabilistic method accounts for variability in material properties (such as hydraulic conductivity, shear strength, etc) these variations are usually not temporal. A usually implicit assumption in the geotechnical design process is that properties such as those listed do not change with time and can be characterised by appropriate test procedures carried out either during the design phase (usually laboratory tests) or immediately after construction is complete, such as the in-situ hydraulic conductivity tests carried out on many sites where covers have been constructed. We argue that for facilities such as the cover systems used for tailings storage facilities and waste rock dumps, it is essential to begin to incorporate temporal changes in soil properties and to build these into the design process. Easier said than done.

Recognising that incorporation of both spatial and temporal uncertainty into the design process is challenging, an approach is suggested that is built on a revised view of the relationship between engineering and ecological processes.

Figure 4 summarises the suggested approach, in which the conventional (as we perceive it) approach is contrasted with an integrated approach. Although the differences might appear relatively trivial, the implications are not, as discussed later. The conventional approach is essentially one of linearity; geotechnical design is completed ahead of construction, which then proceeds on the basis of the engineering design. Once the engineering infrastructure, such as drainage facilities and reshaped waste facilities, has been developed, ecosystem design and reconstruction begins, usually initiated by some degree of revegetation. Long term management is then handled by ecologists, with engineers usually closed out of the process, unless some component of the engineering infrastructure malfunctions, at which point they are usually brought in merely to implement remedial measures and then again hand back management of the system to other professions. 
(a)

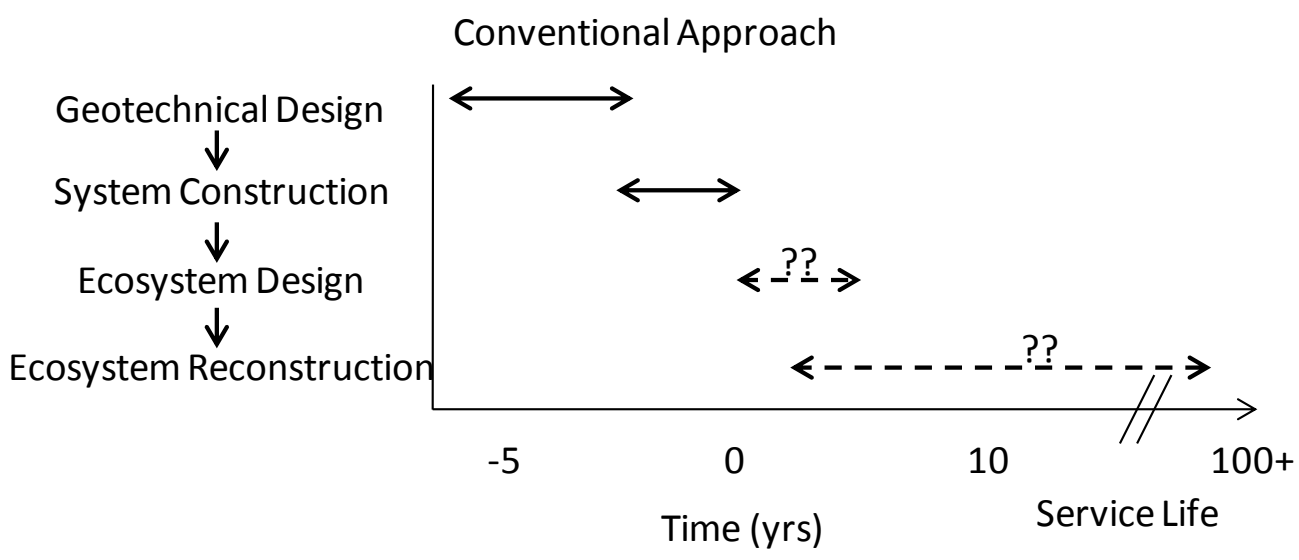

(b)

Integrated Approach

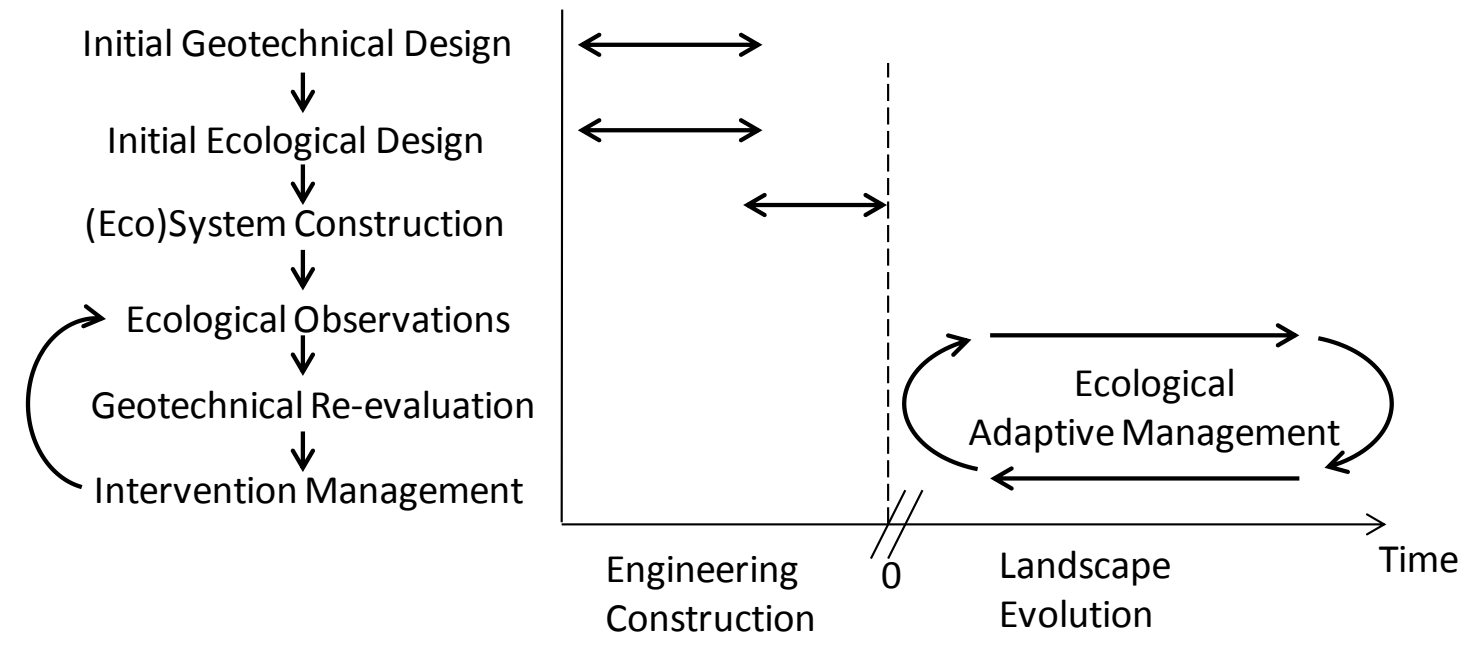

Figure $4 \begin{aligned} & \text { Changes in engineered landscape development in stages that currently and } \\ & \text { might occur under (a) conventional design approach and (b) proposed } \\ & \text { integrated approach }\end{aligned}$

The proposed, integrated approach incorporates ecological input at an earlier stage, building it into the geotechnical design phase. It includes some earlier 'ecological' construction, which might be something as simple as ensuring adequate attention is paid to protection of soil stockpiles in an ecologically responsible way. Of more importance in the integrated approach is the loop designated, 'ecological adaptive management', which requires that ecological observations inform geotechnical re-evaluation and perhaps, should conditions warrant it, intervention management. A simple example could be the identification, at the design phase, of indigenous vegetation that has unacceptably deep root systems. If the cover cannot be designed and constructed in such a way that it cannot be expected to function satisfactorily for its design life (perpetuity?), then changes to the design should be made. This could include, for example, the compaction of a dense layer of non-clayey material at a depth considered to be beyond the rooting zone of the vegetation chosen for the cover system. Even this, apparently simple solution is fraught with complexities. As shown by Fourie et al. (2008), some indigenous plant species in Australia are able to penetrate soil layers compacted to densities that the literature indicates should render them immune to root penetration.

The integrated approach would require some re-thinking of an approach to engineering design that is based on one-off measurements of key engineering parameters, such as those made immediately after completion of construction. What is required is an implicit acceptance that such parameters may, and usually do, change in time and to ensure reactive measures are possible to accommodate the range of possible changes, if necessary. Interestingly, this approach is not entirely foreign to the geotechnical 
community. A common approach, known as the 'Observational Method' is increasingly favoured. The driver for this approach, in which select measurements are made during the service life of a facility, such as deflections of a new type of bridge structure, and the results of these measurements used to corroborate (or not) certain design assumptions, is the difficulty of always being able to test and quantify all the key engineering parameters prior to construction. The Observational Approach is sometimes interpreted to mean, let's just see what happens, and then we'll deal with it. This is not the function of the Observational Approach. In the Observational Approach, possible outcomes are identified beforehand, and solutions to those outcomes are developed at the commencement of the Approach. Although not based on the same premise as the Observational Approach, the approach advocated in Figure 4 is similar in nature. It requires the tacit acceptance of the need to make meaningful measurements (i.e. not a simple check-list approach) that quantify performance. If deemed necessary, a procedure for intervening in such a way that both engineering and ecological requirements are achieved for the design life of the facility is then implemented. This does not necessarily imply that monitoring and measurement is an interminable process. It might well be that at some time in the future the facility will reach a state of stable evolution, where the managers may have a very high degree of confidence that no unrecognised engineering failure modes are conceivable.

\section{$5 \quad$ Concluding comments}

The successful design, construction and performance of cover systems for tailings storage and waste rock facilities depends crucially on geotechnical engineering input. This particular application is, however, significantly different from most other geotechnical problems, such as building foundations, retaining structures, tunnels and earth dams, where the majority of the construction material (the soil) is buried below surface and hardly influenced by environmental and biotic processes. Cover systems, in contrast, are highly dependent on interactions with the atmosphere (e.g. desiccation induced cracking of clay covers) and with ecological processes that occur in and on the construction material (the soil cover).

This paper argues that successful implementation of soil cover systems will be enhanced through the recognition, by both geotechnical engineers and ecologists, that an integrated approach, in which the expertise and experience of both disciplines (and indeed other disciplines such as hydrology, etc) are both essential to ensuring a successful outcome. An integrated approach is advocated, in which ecological expertise is incorporated in the design and construction stage, and where geotechnical expertise is included in post-closure monitoring and evaluation processes, enabling appropriate interventions to be made timeously.

The concepts suggested in this paper are relatively simple in overview, but potentially extremely complex in implementation. It will require changes in approach by some engineers and some ecologists, would benefit from changes (probably relatively minor) in some teaching programmes, and a recognition by senior managers that the conventional, linear approach to closure is inherently flawed. Examples could include changes in compaction specifications that acknowledge the potential for compacted density to influence vegetation establish, and the use of hydraulic conductivity values in modelling exercises that account for the almost inevitable changes that will occur post-construction. If we continue with the conventional approach, it is more likely to require costly interventions to ensure success, whereas an approach that identifies potential evolutionary changes and designs for them at the outset will, in the end, be much more economical.

\section{Acknowledgements}

Funding provided by the United States National Science Foundation (\#0727463), Geosyntec Inc. and the UC Discovery Grant Program in support of the research by Jason T. DeJong. Any opinions, findings and conclusions or recommendations expressed in this material are those of the writer(s) and do not necessarily reflect the views of the National Science Foundation. 


\section{References}

Albright, W., Benson, C., Gee, G., Roesler, A., Abichou, T., Apiwantragoon, P., Lyles, B. and Rock, S. (2004) Field water balance of final covers, Journal of Environmental Quality, Vol. 33(6), pp. 2317-2332.

Baecher, G. and Christian, J. (2003) Reliability and Statistics in Geotechnical Engineering, Wiley, 618 p.

Banning, N.C., Grant, C.D., Jones, D.L. and Murphy, D.V. (2008) Recovery of soil organic matter, organic matter turnover and nitrogen cycling in a post-mining forest rehabilitation chronosequence, Soil Biology \& Biochemistry, Vol. 40, pp. 2021-2031.

Benson, C., Sawangsuriya, A., Trzebiatowski, B. and Albright, W. (2007) Postconstruction changes in the hydraulic properties of water balance cover soils, ASCE Journal of Geotechnical and Geoenvironmental Engineering, Vol. 133(4), pp. 349-359.

Bishop, D.M. and Stevens, M.E. (1964) Landslides on logged areas in southeast Alaska, U.S. Forest Service Research Paper NOR-1, Juneau, Alaska, p. 18.

Chenu, C. (1995) Extracellular polysaccharides: An interface between microorganisms and soil constituents, in Environmental impact of soil component interactions: Land quality, natural and anthropogenic organics, P.M. Huang, J. Berthelin, J-M. Bollag and W.B. McGill (eds), Vol. 1, CRC Press, Boca Raton, FL, pp. 217-233.

Emerson, W.W. (1967) A Classification of Soil Aggregates Based on Their Coherence in Water, Australian Journal of Soil Research, Vol. 5, pp. 47-57.

Fourie, A.B. (2007) The engineering contribution of vegetation to the stability of cover systems, in Proceedings Second International Seminar on Mine Closure (Mine Closure 2007), A.B. Fourie, M. Tibbett and J.V. Wiertz (eds), 16-19 October 2007, Santiago, Chile, Australian Centre for Geomechanics, Perth, pp. 483-493.

Fourie, A.B. and Tibbett, M. (2007) Post-mining landforms: engineering a biological system, Keynote Lecture, in Proceedings Second International Seminar on Mine Closure (Mine Closure 2007), A.B. Fourie, M. Tibbett and J.V. Wiertz (eds), 16-19 October 2007, Santiago, Chile, Australian Centre for Geomechanics, Perth, pp. 3-12.

Fourie, A.B., Tibbett, M., Worthington, T. and King, A.E. (2008) Quantifying the effect of substrate compaction on root development in cover systems, in Proceedings Third International Seminar on Mine Closure (Mine Closure 2008), A.B. Fourie and M. Tibbett, I.M. Weiersbye and P. Dye (eds), 14-17 October 2008, Johannesburg, South Africa, Australian Centre for Geomechanics, Perth, pp. 27-34.

Gray, D.H. (1970) Effects of forest clear-cutting on the stability of natural slopes, Bulletin of the Association of Engineering Geologists, Vol. 7(1-2), pp. 45-66.

Gray, D.H. and Sotir, R.B. (1996) Biotechnical and Soil BioEngineering Stabilization, John Wiley \& Sons, 378 p.

Jackson, R.B., Canadell, J., Ehleringer, J.R., Mooney, H.A., Sala, O.E. and Schulze, E.D. (1996) A global analysis of root distributions for terrestrial biomes, Oecologia, Vol. 108, pp. 389-411.

Majer, J.D., Day, J.E., Kabay, E.D. and Perriman, W.S. (1984) Recolonization by ants in Bauxite Mines rehabilitated by a number of different methods, Journal of Applied Ecology, Vol. 21, pp. 355-375.

Mitchell, J.K. and Santamarina, J.C. (2005) Biological considerations in geotechnical engineering, ASCE Journal of Geotechnical and Geoenvironmental Engineering, Vol. 131(10), pp. 1222-1233.

Operstein, V. and Frydman, S. (2000) The influence of vegetation on soil strength, Ground Improvement, Vol. 4, pp. 81-89.

Or, D., Phutane, S. and Dechesne, A. (2007) Extracellular polymeric substances affecting pore-scale hydrologic conditions for bacterial activity in unsaturated soils, Vadose Zone Journal, Vol. 6, pp. 298-305.

Rice, R.M. and Krammes, J.S. (1970) Mass-wasting processes in watershed management, in Proceedings Symposium Interdisciplinary aspects of watershed management, Bozeman, Montana, August, ASCE, New York, pp. 231-260.

Spain, A.V. and Tibbett, M. (2011) Substrate conditions, root and arbuscular mycorrhizal colonisation of landforms rehabilitated after coal mining, sub-tropical Queensland, in Proceedings Sixth International Conference on Mine Closure (Mine Closure 2011), A.B. Fourie, M. Tibbett and A. Beersing (eds), 19-21 September 2011, Lake Louise, Canada, Australian Centre for Geomechanics, Perth, Vol. 1, pp. 199-208.

Spain, A.V., Hinz, D. and Tibbett, M. (2010) Colonisation of rehabilitated lands by termites (Dictyoptera), Rio Tinto Alcan Gove bauxite mine, Northern Territory, Australia, in Proceedings Fifth International Conference on Mine Closure (Mine Closure 2010), A.B. Fourie, M. Tibbett and J. Wiertz (eds), 23-26 November 2010, Viña del Mar, Chile, Australian Centre for Geomechanics, Perth, pp. 437-448.

Spain, A.V., Hinz, D.A., Ludwig, J., Tibbett, M. and Tongway, D. (2006) Mine closure and ecosystem development: Alcan Gove bauxite mine, NT, Australia, in Proceedings First International Seminar on Mine Closure (Mine Closure 2006), A.B. Fourie and M. Tibbett (eds), 13-15 September 2006, Perth, Australia, Australian Centre for Geomechanics, Perth, pp. 299-308.

Spain, A.V., Ludwig, J., Tibbett, M. and Tongway, D. (2009) Ecological and Minesoil Development Studies at the Rio Tinto Alcan Gove Mine site, Northern Territory, Centre for Land Rehabilitation, Perth.

Sutherland, I.W. (2001) Biofilm exopolysaccharides: A strong and sticky framework, Microbiology, Vol. 147, pp. 3-9.

Taylor, G., Spain, A., Nefiodovas, A., Timms, G., Kuznetsov, V. and Bennett, J. (2003) Determination of the reasons for deterioration of the Rum Jungle waste rock cover, Australian Centre for Mining Environmental Research, Brisbane.

Terzaghi, K., Peck, R.B. and Mesri, G. (1996) Soil Mechanics in Engineering Practice, Wiley, 592 p.

Tibbett, M. (2010), Large-scale Mine Site Restoration of Australian Eucalypt Forests after Bauxite Mining: Soil Management and Ecosystem Development, in Ecology of Industrial Pollution, L.C. Batty and K. Hallberg (eds), Cambridge University Press, UK, pp. 309-326.

Tongway, D.J. and Hindley, N.L. (1998) An Ecological Assessment of Internally Draining Landforms at Oaky Creek Coal Mine, CSIRO Wildlife and Ecology Report, $58 \mathrm{p}$.

Tongway, D.J. and Ludwig, J.A. (2011) Restoring Disturbed Landscapes, Island Press, Washington DC, 189 p. 
Waldron, L.J. (1977) The shear resistance of root-permeated homogeneous and stratified soil, Soil Science Society of America Journal, Vol. 41, pp. 843-849.

Waldron, L.J. and Dakessian, S. (1982) Effect of grass, legume, and tree roots on soil shearing resistance, Soil Science Society of America Journal, Vol. 46, pp. 894-899.

Watson, A. and O'Loughlin, C. (1985) Morphology, strength and biomass of manuka roots and their influence on slope stability, New Zealand Journal of Forestry Science, Vol. 15(3), pp. 337-348. 